\title{
TITLE:
}

\section{Thermal stabilization of levoglucosan in aromatic substances}

\section{AUTHOR(S):}

Hosoya, Takashi; Kawamoto, Haruo; Saka, Shiro

\section{CITATION:}

Hosoya, Takashi ...[et al]. Thermal stabilization of levoglucosan in

aromatic substances. Carbohydrate Research 2006, 341(13): 2293-2297

\section{ISSUE DATE:}

2006-09-25

URL:

http://hdl.handle.net/2433/240781

\section{RIGHT:}

(c) 2006. This manuscript version is made available under the CC-BY-NC-ND 4.0 license

http://creativecommons.org/licenses/by-nc-nd/4.0/; The full-text file will be made open to the public on 25 September 2008 in accordance with publisher's 'Terms and Conditions for Self-Archiving'.; This is not the published version. Please cite only the published version.; この論文は出版社版でありません。引用の際には出版社版をご確認ご利用ください。 
Title:

Thermal Stabilization of Levoglucosan in Aromatic Substances

\title{
Authors and affiliation:
}

Takashi Hosoya, Haruo Kawamoto*, Shiro Saka

* Corresponding author: Tal/ Fax: +81-75-753-4737

Email address: kawamoto@energy.kyoto-u.ac.jp (H. Kawamoto)

Full postal address of the person to whom proofs are to be sent:

Graduate School of Energy Science, Kyoto University

Yoshida-honmachi, Sakyo-ku, Kyoto 606-8501, Japan

\begin{abstract}
:
Thermal degradation of levoglucosan (1,6-anhydro- $\beta$-D-glucopyranose) was substantially suppressed in the presence of some aromatic compounds under the conditions of $\mathrm{N}_{2} / 240-340{ }^{\circ} \mathrm{C} / 15 \mathrm{~min}$. This stabilization effect is also discussed with $\mathrm{CH} / \pi \square$ interaction between levoglucosan and $\pi$-electron in benzene-ring.
\end{abstract}

\section{Keywords:}

Levoglucosan; Anhydrosugar; Thermal; Pyrolysis; Aromatic; $\mathrm{CH} / \pi$ interaction. 
Text:

Levoglucosan (1,6-anhydo- $\beta$-D-glucopyranose) (1) is an important primary pyrolysis product of various glucose-based carbohydrates such as cellulose and starch and known to be degraded further through various secondary pyrolysis reactions including thermal ring-opening polymerization. ${ }^{1-5}$ In our previous papers, this polymerization reaction is proposed as a key reaction which determines the product composition of cellulose pyrolysis [i.e. low molecular weight (MW) products vs. carbonized product]. ${ }^{6,7}$ We also found that thermal polymerization of levoglucosan was inhibited substantially during co-pyrolysis of cellulose with lignin sample (J. Anal. Appl. Pyrolysis, submitted). This paper describes the effects of various aromatic compounds including model compounds 2-4 (Fig. 1) of lignin pyrolysate on thermal stabilization of levoglucosan. Furthermore, stabilization mechanism is also discussed with $\mathrm{CH} / \pi$ interaction.

Pure levoglucosan was converted into the products observed in the higher MW region in the GPC chromatogram (Fig. 2), and levoglucosan recovery was only $3.6 \%$ of the initial amount. Pictet ${ }^{1}$ reported that levoglucosan polymerizes into dextran by heating at $240{ }^{\circ} \mathrm{C}$ for $15-30 \mathrm{~min}$. Thus, these high MW products are considered to be the polymerized products through ring-opening of the bicyclic structure.

Addition of veratrole (4) to this system substantially reduced the polymerized product formation as shown in Fig. 2. High MW products decreased with an increase in the amount of $\mathbf{4}$ and almost completely disappeared at 2.0 mol equiv. Figure 3 
summarizes the levoglucosan recovery against the amount of guaiacol (2), 4-methylguaiacol (3) or veratrole (4). Levoglucosan recovery increased with increasing amount of aromatic compound and became almost quantitative at 1.0-2.0 mol equiv regardless of the chemical structures of aromatic compounds 2-4. These results indicate that neither phenolic $\mathrm{OH}$ nor benzyl group have direct actions to levoglucosan related to the thermal stabilization. As shown in Fig. 4, levoglucosan was recovered almost quantitatively up to $340{ }^{\circ} \mathrm{C}$ under the experimental conditions of levoglucosan (10 mg)/ veratrole $(100 \mu \mathrm{L}) / \mathrm{N}_{2} / 15 \mathrm{~min}$. It is also noted that these levoglucosan/ aromatic compound mixtures became homogeneous during heat treatment. Interestingly, no other thermal decomposition reactions including formation of furfurals and dark colored substances were observed under these stabilizing conditions even at a high temperature of $340{ }^{\circ} \mathrm{C}$. These results suggest an interesting hypothesis that most of the thermal decomposition reactions are closely related to the ring-opening reaction of levoglucosan.

Diluting effect by aromatic compound, which reduces the accessibility of levoglucosan, is considered to be a reason for this stabilization. However, Kawamoto et al. ${ }^{6}$ reported that levoglucosan solution in sulfolane (tetramethylene sulfone) was degraded into other low MW products such as levoglucosenone and furfurals at 200-330 ${ }^{\circ} \mathrm{C}$. From these results, some factors other than diluting effect are indicated as a reason for this stabilization.

In the ${ }^{1} \mathrm{H}$ NMR analysis of levoglucosan/ guaiacol mixture in $\mathrm{D}_{2} \mathrm{O}$, the signals of 
H-4, H-5 and H-6 of levoglucosan were shifted toward higher magnetic fields with addition of an increasing amount of guaiacol (Fig. 5) (assignment of each signal was conducted according to the report of Heyns and Weyer ${ }^{8}$ ). Similar shift was also observed for $\mathrm{H}-1$ and $\mathrm{H}-2$ of levoglucosan, although their extents are smaller than those of H-4, H-5 and H-6. On the other hand, effect of guaiacol addition on the chemical shift of H-3 was comparatively very small. The signals assigned to H-3 and H-4, which were overlapped in the spectrum of pure levoglucosan, were separated in the spectra of levoglucosan/ guaiacol mixture due to higher magnetic field shifting of one signal. These signals were assigned with the ${ }^{1} \mathrm{H}-{ }^{1} \mathrm{H}$ COSY spectrum (Fig. 6).

Interaction between $\mathrm{C}-\mathrm{H}$ and $\pi$ electron system $(\mathrm{CH} / \pi \text { interaction })^{9-27}$ is known to play important roles in conformation of some aromatic compounds, ${ }^{11-14}$ tertiary structure of protein ${ }^{15,16}$ and molecular recognition. ${ }^{10,17-23}$ As for sugar-aromatic interaction, Fernández-Alonso ${ }^{24}$ reported the association of the $\alpha$ face of methyl $\beta$-D-galactopyranoside with benzene or phenol through $\mathrm{CH} / \pi$ interaction from the ${ }^{1} \mathrm{H}$ NMR higher magnetic field shift observed for $\mathrm{H}-1, \mathrm{H}-3, \mathrm{H}-4$ and $\mathrm{H}-5$ of methyl $\beta$-D-galactopyranoside. Generally, $\mathrm{C}-\underline{\mathrm{H}}$ involved in the $\mathrm{CH} / \pi$ interaction is known to be observed in higher magnetic field in ${ }^{1} \mathrm{H}$ NMR analysis, ${ }^{20-26}$ and the extent is positively related to the strength of the $\mathrm{CH} / \pi$ interaction. ${ }^{25,26} \quad$ Therefore, the results of ${ }^{1} \mathrm{H}$ NMR analysis in Fig. 5 indicate the $\mathrm{CH} / \pi$ interaction of aromatic $\pi$ electron with the H-4, H-5, H-6 face and the H-1, H-2 face of levoglucosan as illustrated in Fig. 7. Stronger interaction of the H-4, H-5, H-6 face than the H-1, H-2 face is also 
indicated from the extent of the shifting. Although the data in Fig. 5 are obtained in $\mathrm{D}_{2} \mathrm{O}$, similar complexation between levoglucosan and aromatic compound is also considered in the neat system without $\mathrm{D}_{2} \mathrm{O}$.

Restricted thermal motion of levoglucosan in the complex is considered to be a reason for the stabilization effect since thermal motion is a driving force of levoglucosan thermal decomposition. Especially, ring-opening polymerization of levoglucosan into polysaccharide requires conformational change from ${ }^{1} C_{4}$ to ${ }^{4} C_{1}$ (Scheme 1). This conformational change is expected to be inhibited effectively in the levoglucosan-aromatic compound complex.

Table 1 summarizes the stabilization ability of various aromatic compounds as levoglucosan recovery under the experimental conditions of levoglucosan (10 mg)/ aromatic compound $(100 \mu \mathrm{L}) / \mathrm{N}_{2} / 240{ }^{\circ} \mathrm{C} / 15 \mathrm{~min}$. Both stabilizing ability and levoglucosan solubility in aromatic compound are quite different depending on the chemical structure of aromatic compound, and have a tendency to be positively related to the $\pi$ electron density. These results also support the hypothesis of the stabilizing mechanism through $\mathrm{CH} / \pi$ interaction, which is known to be enhanced with higher $\pi$ electron density. ${ }^{9,10,25-27}$ Low stabilization abilities of benzene, chlorobenzene and dichlorobenzene are conceivable with their low $\pi$ electron densities not enough to form the stable levoglucosan-aromatic compound complexes.

The present results disclose the complexation of anhydrosugar having ${ }^{1} C_{4}$ conformation with the $\pi$ electron of benzene-ring, and this information is expected to 
promote the anhydrosugar chemistry related to the interaction with other substances. Furthermore, the present finding of the reduced thermal reactivity of levoglucosan-aromatic complex will give useful information to control the product selectivity in carbohydrate pyrolysis.

\section{Experimental}

\subsection{Materials}

Levoglucosan was purchased from Tokyo Kasei co. and the other chemicals were purchased from Nacalai Tesque co. as guaranteed grades.

\subsection{Heat treatment and characterization of the products}

Levoglucosan (10 mg) was heated in a closed Pyrex glass ampoule (internal diameter: $2.0 \mathrm{~mm}$, length: $30 \mathrm{~mm}$, thickness; $1.0 \mathrm{~mm}$ ) under the conditions of $\mathrm{N}_{2} / 240$ ${ }^{\circ} \mathrm{C} / 15 \mathrm{~min}$ with or without aromatic compound (0.2-2.0 mol equiv to levoglucosan). After immediate cooling with cold water to quench the reaction, the ampoule was opened and extracted with distilled water $(1.0 \mathrm{~mL})$. The water-soluble portion was characterized with gel permeation chromatography (GPC) using Shimadz LC-10A under the chromatographic conditions: column: Shodex Asahipak GS-320 HQ + Asahipak GS-220 HQ, flow rate: $0.6 \mathrm{~mL} \mathrm{~min}{ }^{-1}$, eluent: water, detector: RI, temperature: 
$30{ }^{\circ} \mathrm{C}$. Levoglucosan recovery was also determined with gas chromatographic analysis (detector: flame ionization) of the water-soluble portion with myo-inositol as an internal standard after evaporating water in vacuo followed by trimethylsilylation with $\mathrm{N}, \mathrm{O}$-bis (trimethylsilyl) trifluoroacetamide: trimethylchlorosilane: pyridine $(2: 1: 7, \mathrm{v} / \mathrm{v} / \mathrm{v})$ using Shimadz GC-18B under the chromatographic conditions: column: Shimadz CBP-5 (25 $\mathrm{m} \times 0.25 \mathrm{~mm} \Phi)$, injector temperature: $250{ }^{\circ} \mathrm{C}$, column temperature: $180{ }^{\circ} \mathrm{C}(1.0 \mathrm{~min})$, $180 \rightarrow 260{ }^{\circ} \mathrm{C}(1.0 \rightarrow 9.0 \mathrm{~min}), 260{ }^{\circ} \mathrm{C}(9.0 \rightarrow 19.0 \mathrm{~min})$, carrier gas: helium, flow rate: 1.5 $\mathrm{mL} \min ^{-1}$.

\section{$1.3{ }^{1} \mathrm{H}$ NMR analysis}

Levoglucosan (1.6 mg, $10 \mu \mathrm{mol})$ was dissolved in $\mathrm{D}_{2} \mathrm{O}(1.0 \mathrm{~mL})$ including 1.2$18.6 \mathrm{mg}(10-150 \mu \mathrm{mol})$ of guaiacol. After ultrasonic wave treatment for $10 \mathrm{~min}$, the solution was used as ${ }^{1} \mathrm{H}$ NMR sample. $\quad{ }^{1} \mathrm{H}$ NMR analysis was conducted with a Bruker AC-400 (400 MHz) spectrometer: levoglucosan: $\delta 5.25$ (s, 1H, H-1), 4.43 (m, 1H, H-5), 3.89 (dd, 1H, J 1.0, 7.7 Hz, H-6a), 3.56 (dd, 1H, J 5.8, 7.7 Hz, H-6b), 3.48 (m, 2H, H-3 and $\mathrm{H}-4$ ), 3.33 (dd, $1 \mathrm{H}, J$ 1.6, $3.2 \mathrm{~Hz}, \mathrm{H}-2$ ). 


\section{References:}

1 Pictet, A. Helv. Chim. Acta 1918, 1, 226-230.

2 Wolfrom, M. L.; Thompson, A.; Ward, R. B. J. Am. Chem. Soc. 1959, 81, 4623-4625.

3 Wolfrom, M. L.; Thompson, A.; Ward, R. B.; Horton, D.; Moore, R. H. J. Org. Chem. 1961, 26, 4617-4620.

4 Shafizadeh, F.; Philpot, C. W.; Ostojic, N. Carbohydr. Res. 1971, 16, 279-287.

5 Schuerch, C. Adv. Carbohydr. Chem. Biochem. 1981, 39, 157-212.

6 Kawamoto, H.; Hatanaka, W; Saka, S. J. Anal. Appl. Pyrolysis 2003, 70, 303-313.

7 Kawamoto, H.; Murayama, M.; Saka, S. J. Wood. Sci. 2003, 49, 469-473.

8 Heyns, K.; Weyer, J. Liebigs Ann. Chem. 1968, 718, 224-237.

9 Nishio, M.; Hirota, M. Tetrahedron 1989, 45, 7201-7245.

10 Nishio, M.; Umezawa, Y.; Hirota, M.; Takeuchi, Y. Tetrahedron 1995, 51, 8665-8701.

11 Nakai, Y.; Yamamoto, G.; Oki, M. Chem. Lett. 1987, 89-92.

12 Kodama, Y.; Zushi, S.; Nishihata, K.; Nishio, M. J. Chem. Soc.,Perkin Trans. 2 1980, 1306-1312.

13 Nakai, Y.; Inoue, K.; Yamamoto, G.; Oki, M. Bull. Chem. Soc. Jpn. 1989, 62, 2923-2931. 
14 Iwamoto, H.; Takahashi, N.; Maeda, T.; Hidaka, Y.; Fukazawa, Y. Tetrahedron Lett. 2005, 46, 6839-6842.

15 Weis, W. I. Annu. Rev. Biochem. 1996, 65, 441-473.

16 Bazzicalupi, C.; Dapporto, P. Struct. Chem. 2004, 15, 259-268.

17 Re, S.; Nagase, S. Chem. Commun. (Cambridge) 2004, 658-659.

18 Bernardi, A.; Arosio, D.; Potenza, D.; Sánchez-Medina, I.; Mari, S.; Cañada, F. J.; Jiménez-Barbero, J. Chem. Eur. J. 2004, 10, 4395-4406.

19 Spiwok, V.; Lipovová, P.; Skálová, T.; Buchtelová, E.; Hašek, J.; Králová, B. Carbohydr. Res. 2004, 339, 2275-2280.

20 Kobayashi, K.; Asakawa, Y.; Kato, Y.; Aoyama, Y. J. Am. Chem. Soc. 1992, 114, 10307-10313.

21 Kobayashi, K.; Ishii, K.; Sakamoto, S.; Shirasaka, T.; Yamaguchi, K. J. Am. Chem. Soc. 2003, 125, 10615-10624.

22 Kobayashi, K.; Asakawa, Y.; Kikuchi, Y.; Toi, H.; Aoyama, Y. J. Am. Chem. Soc. 1993, 115, 2648-2654.

23 Tashiro, S.; Tominaga, M.; Kawano, M.; Therrien, B.; Ozeki, T.; Fujita, M. J. Am. Chem. Soc. 2005, 127, 4546-4547.

24 Fernández-Alonso, M. del C.; Cañada, F. J., Jiménez-Barbero, J.; Cuevas, G. J. Am. Chem. Soc. 2005, 127, 7379-7386.

25 Ehama, R.; Tsushima, M.; Yuzuri, T.; Suezawa, H.; Sakakibara, K.; Hirota, M. Bull. Chem. Soc. Jpn. 1993, 66, 814-818. 
26 Suezawa, H.; Hashimoto, T.; Tsuchinaga, K.; Yoshida, T.; Yuzuri, T.; Sakakibara, K.; Hirota, M.; Nishio, M. J. Chem. Soc.,Perkin Trans. 2 2000, 1243-1249.

27 Hirota, M.; Sakakibara, K.; Suezawa, H.; Yuzuri, T.; Ankai, E.; Nishio, M. J. Phys.

Org. Chem. 2000, 13, 620-623. 


\section{Legend of figures and scheme}

Figure 1. Chemical structures of levoglucosan (1), guaiacol (2), 4-methylguaiacol (3), veratrole (4).

Figure 2. GPC chromatograms after heat treatment of levoglucosan/ veratrole (4) under the conditions of $\mathrm{N}_{2} / 240^{\circ} \mathrm{C} / 15$ min. (*) retention time of levoglucosan. detector: RI.

Figure 3. Levoglucosan recovery in aromatic compounds 2-4 after heat treatment under

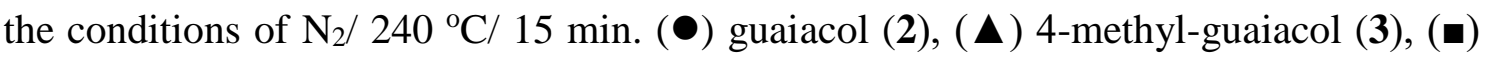
veratrole (4).

Figure 4. Effects of temperature on levoglucosan recovery in veratrole (4) after heat treatment in $\mathrm{N}_{2}$ for 15 min.

Figure 5. Effects of guaiacol (2) addition on the chemical shift of levoglucosan-protons in ${ }^{1} \mathrm{H}$ NMR analysis in $\mathrm{D}_{2} \mathrm{O} .(\bullet) \mathrm{H}-1,(\boldsymbol{\Delta}) \mathrm{H}-2,(\boldsymbol{\bullet}) \mathrm{H}-3,(\bigcirc) \mathrm{H}-4,(\triangle) \mathrm{H}-5,(\square) \mathrm{H}-6 \mathrm{a}$, $(\diamond)$ H-6b.

Figure 6. ${ }^{1} \mathrm{H}-{ }^{1} \mathrm{H}$ COSY spectrum (400 MHz) of a levoglucosan/ guaiacol (15 mol equiv) mixture in $\mathrm{D}_{2} \mathrm{O} . \quad(\times)$ derived from impurity in guaiacol. 
Figure 7. Levoglucosan-aromatic-ring complexation indicated from the $\Delta \delta \square$ in ${ }^{1} \mathrm{H}$ NMR analysis of levoglucosan-guaiacol mixture in $\mathrm{D}_{2} \mathrm{O}$.

Scheme 1. Conformation change of levoglucosan in the ring-opening polymerization into polysaccharide. 


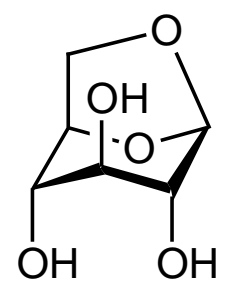

Levoglucosan (1)<smiles>COc1ccccc1O</smiles>

Guaiacol (2)<smiles>COc1cc(C)ccc1O</smiles>

4-Methylguaiacol (3)<smiles>COc1ccccc1OC</smiles>

Veratrole (4) 


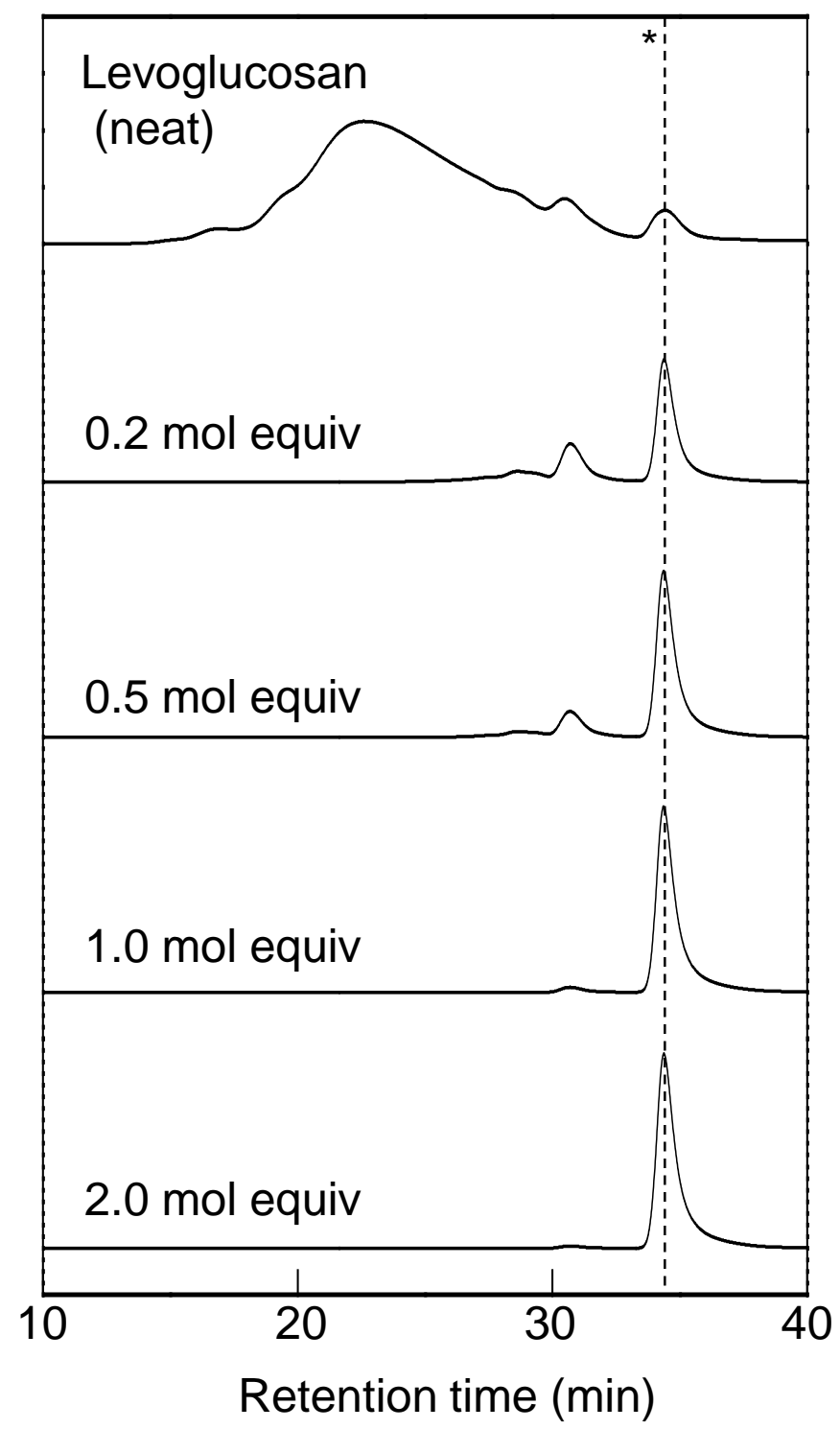




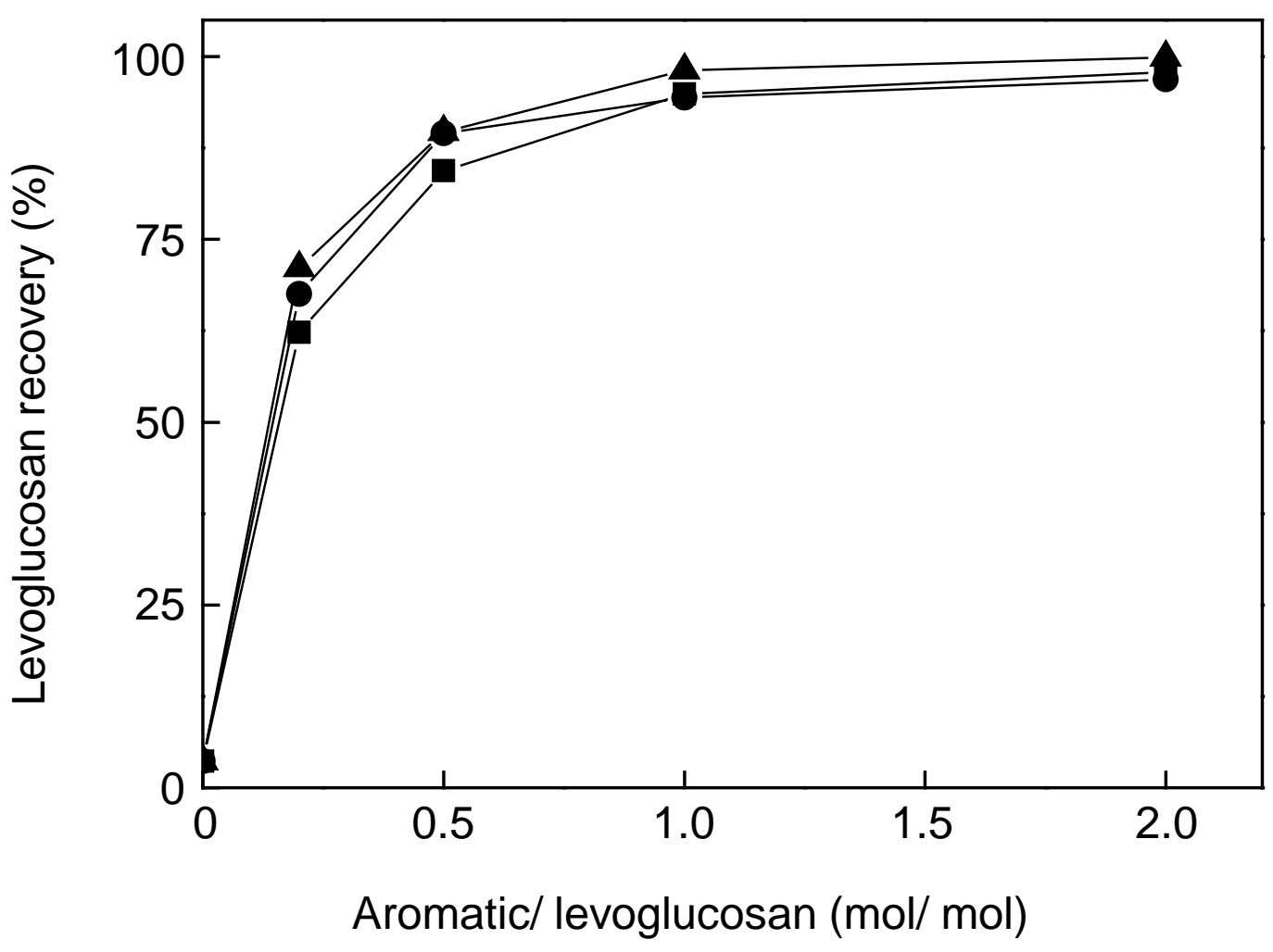




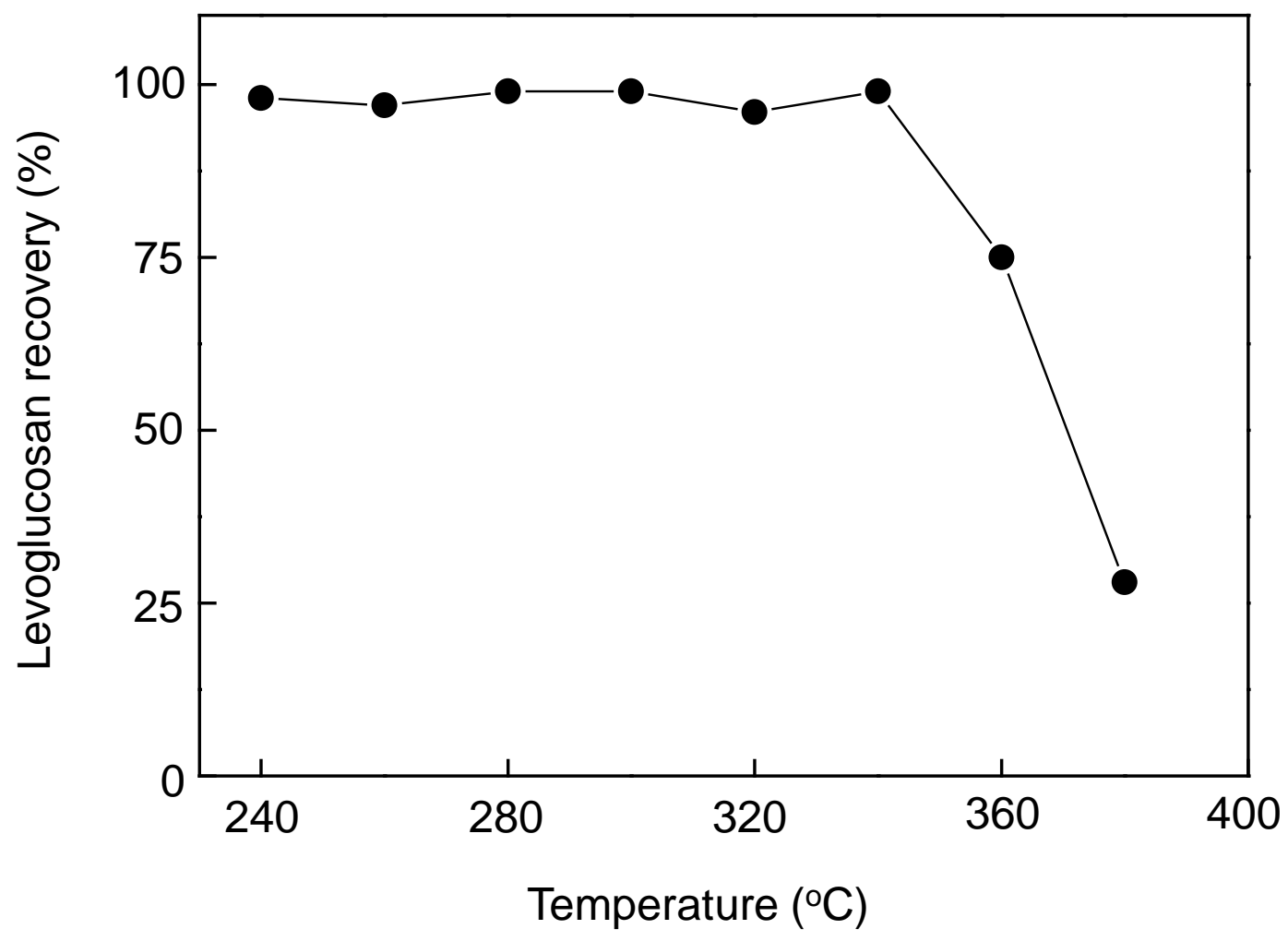




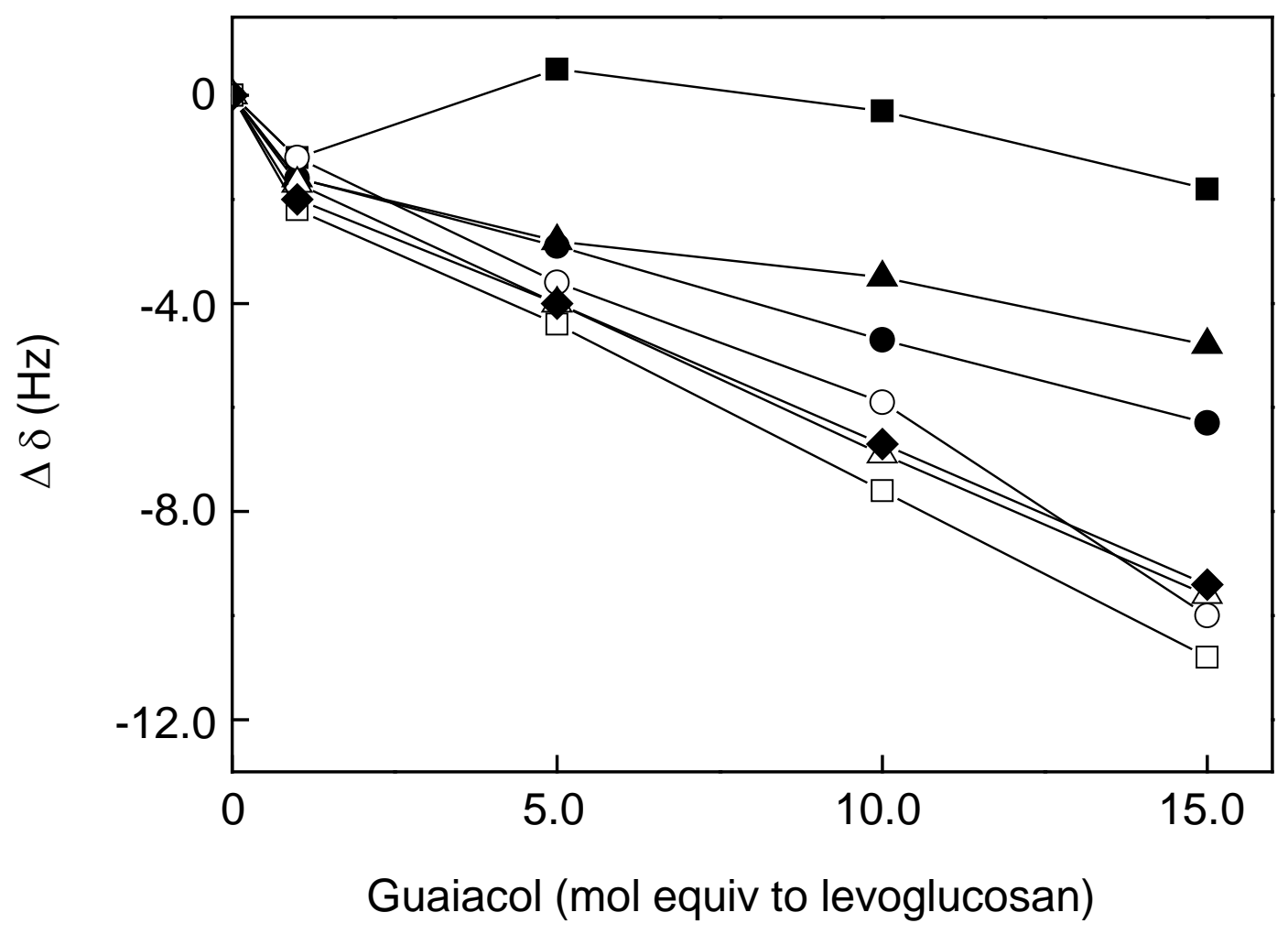




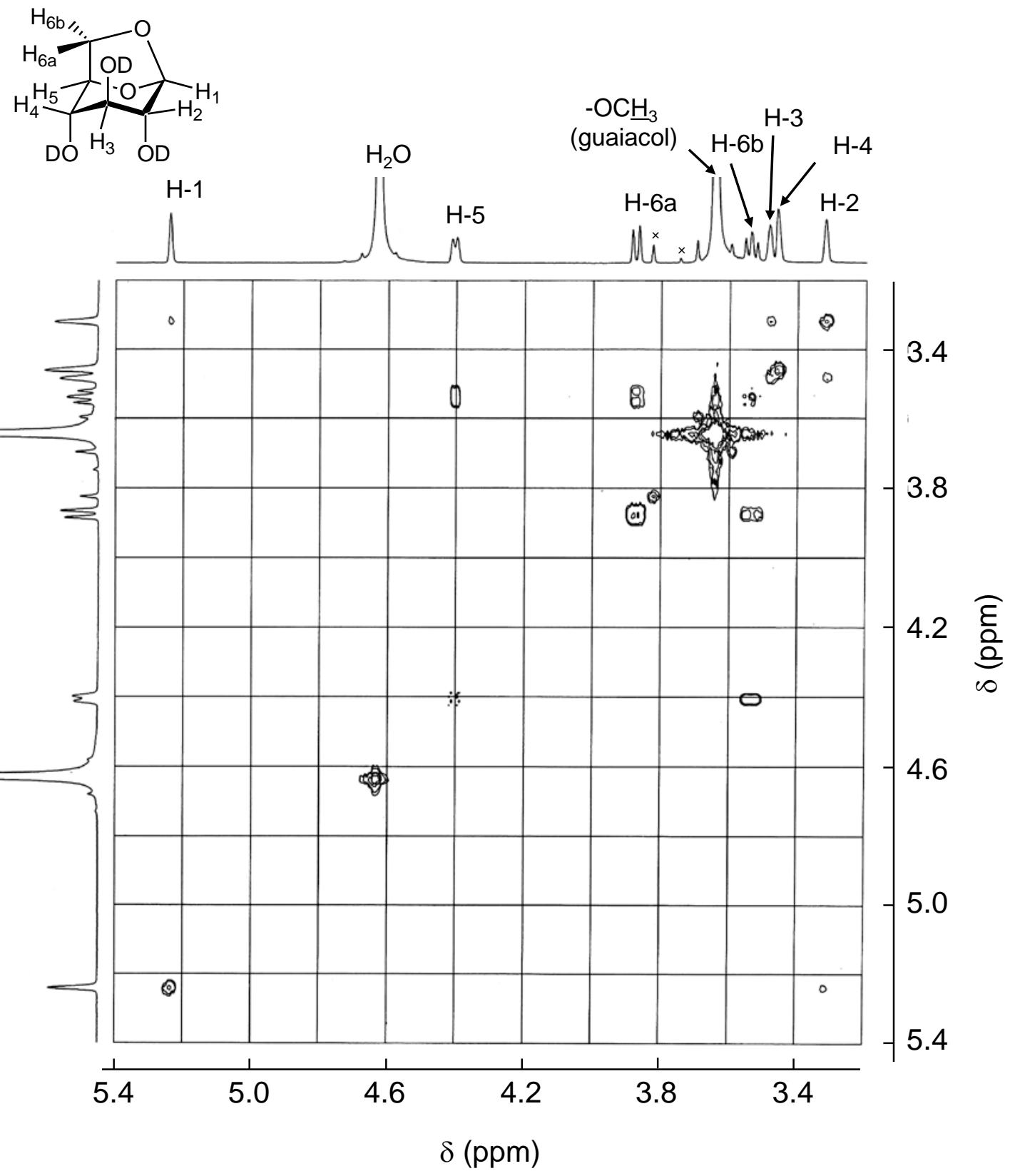




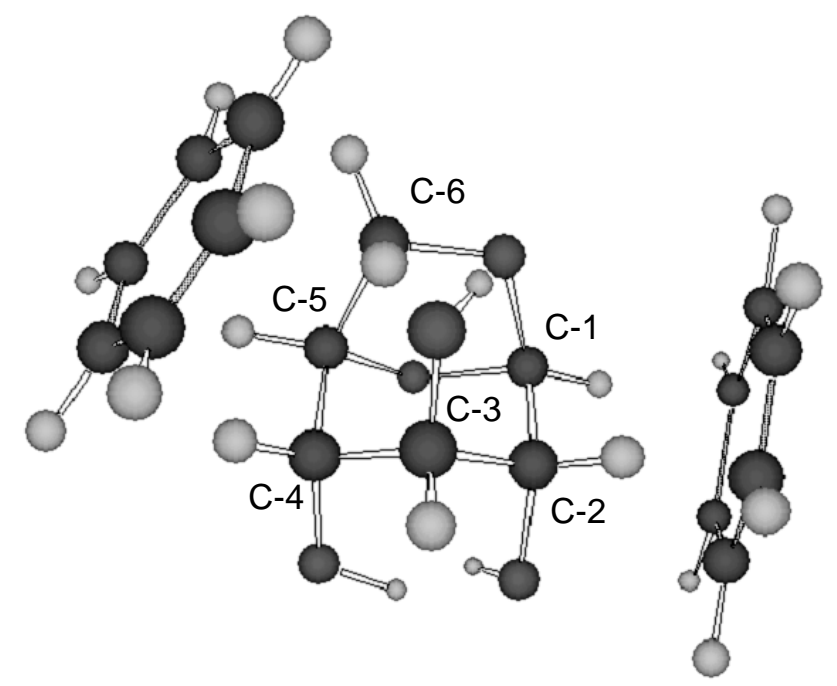




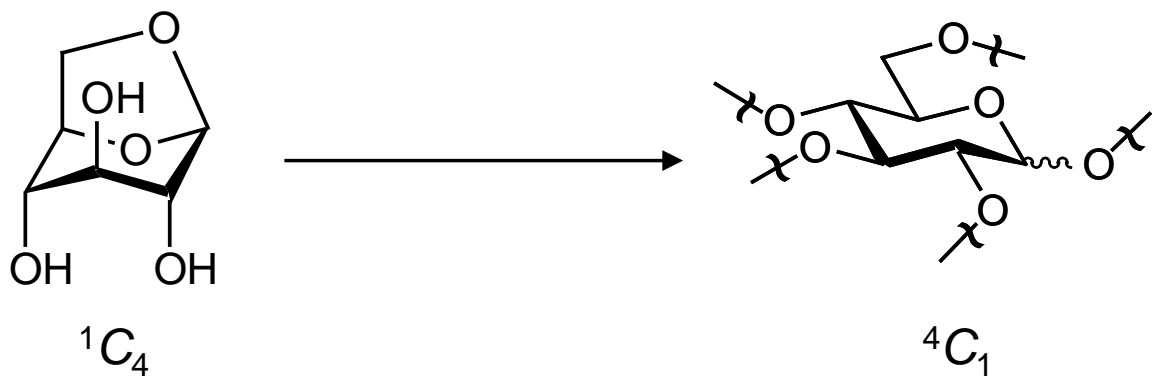


Table 1. Solubility of levoglucosan in various aromatic compounds and levoglucosan recovery after the heat treatment under the conditions of levoglucosan $(10.0 \mathrm{mg}) /$ aromatic compound $(100 \mathrm{ml}) / \mathrm{N}_{2} / 240^{\circ} \mathrm{C} / 15$ min.

\begin{tabular}{|c|c|c|}
\hline $\begin{array}{l}\text { Aromatic } \\
\text { compound }\end{array}$ & $\begin{array}{l}\text { Levoglucosan } \\
\text { solubility }\end{array}$ & $\begin{array}{l}\text { Levoglucosan } \\
\text { recovery (\%) }\end{array}$ \\
\hline & $++a$ & 99.8 \\
\hline & ++ & 96.9 \\
\hline & ++ & 97.6 \\
\hline & ++ & 96.4 \\
\hline & ++ & 89.1 \\
\hline & $+b$ & 82.5 \\
\hline & + & 87.6 \\
\hline & $\pm c$ & 33.5 \\
\hline & $-{ }^{d}$ & 8.3 \\
\hline & - & 7.3 \\
\hline
\end{tabular}

${ }^{a}$ Levoglucosan was completely dissolved. ${ }^{b}$ Levoglucosan was partially dissolved and gave small amount of yellow-colored residue afetr heat treatment. ${ }^{c}$ Levoglucosan was partially dissolved and gave substantial amount of dark-colored residue afetr heat treatment. ${ }^{d}$ Levoglucosan was not dissolved and gave dark-colored residue after heat treatment. 